\title{
Variation of the intercalating proline in artificial peptides mimicking the DNA binding and bending IHF protein
}

\author{
S. Scholz • E. K. Liebler $\cdot$ B. Eickmann • \\ H.-J. Fritz $\cdot$ U. Diederichsen
}

Received: 13 January 2011/Accepted: 29 August 2011/Published online: 16 September 2011

(C) The Author(s) 2011. This article is published with open access at Springerlink.com

\begin{abstract}
The integration host factor (IHF) is a protein which sequence specifically induces a bend of doublestranded DNA by more than $160^{\circ}$. Based on IHF as lead structure, a peptide mimic was introduced resembling the positively charged body of the protein by a lysine dendrimer and the minor groove recognition loop by a cyclopeptide. The proline located close to the tip of the recognition loop intercalates between the base pair plane. It was modified in order to evaluate the influence of the side chain residue with respect to size (1,2,3,4-tetrahydroisoquinoline-3-carboxylic acid), aromaticity (phenylalanine), conformation of the five-membered ring [(4R)-fluoroproline, (4S)-fluoroproline, 3,4-dehydroproline], and the peptide backbone conformation ( $\alpha$-methylproline) on binding dsDNA and bending the double strand. Binding and bending studies were carried out by fluorescence resonance energy transfer experiments and gel electrophoresis using DNA sequences prepared by PCR with the IHF binding site in central or terminal position. Whereas aromatic residues and $\alpha$-methylproline were not tolerated as proline substitute, incorporation of (4S)-fluoroproline and 3,4-dehydroproline provided enhanced binding.
\end{abstract}

Keywords Amino acids - DNA binding and bending . IHF protein $\cdot$ Conformation $\cdot$ Peptides

S. Scholz · E. K. Liebler · B. Eickmann · U. Diederichsen ( $\square)$ Institut für Organische und Biomolekulare Chemie,

Georg-August-Universität Göttingen, Tammannstr. 2,

37077 Göttingen, Germany

e-mail: udieder@gwdg.de

H.-J. Fritz

Institut für Mikrobiologie und Genetik,

Georg-August-Universität Göttingen,

Grisebachstr. 8, 37077 Göttingen, Germany

\section{Introduction}

Prokaryotic cells contain a number of small DNA-binding proteins with the primary function of compacting and organizing genomic DNA (Grove and Saavedra 2002). The integration host factor (IHF) belongs to the group of histone-like proteins (Bewley et al. 1998; Drlica and RouviereYaniv 1987). It has been characterized by X-ray structural analysis as a small heterodimeric protein consisting of two related $\alpha$ and $\beta$ subunits, each with a molecular weight of about 10 kDA (Fig. 1) (Rice et al. 1996; Pettijohn 1988). IHF binds DNA with considerable sequence specificity and affects many cellular processes. Facilitation of $\lambda$ phage integration and involvement in the transcriptional regulation of gene expression and DNA replication binding to oriC are functions of IHF in Escherichia coli (Moitoso de Vargas et al. 1989; Ussery et al. 2001; Filutowicz and Appelt 1988). A highly conserved consensus sequence within the binding sites $\left(\mathrm{H} 1, \mathrm{H} 2, \mathrm{H}^{\prime}\right)$ of the phage attachment area is recognized by IHF (Rice et al. 1996; Friedman 1988). The co-crystal structure of IHF with a $35 \mathrm{bp}$ DNA containing the $\mathrm{H}^{\prime}$-binding site of the $\lambda$ phage reveals that the two subunits are intertwined to form a compact largely $\alpha$-helical body from which two long $\beta$-ribbon arms extend (Fig. 1). These arms recognize dsDNA in the minor groove, whereas the positively charged protein core interacts nonspecifically mainly with the poly-anionic DNA backbone, inducing a bend of at least $160^{\circ}$. Proline residues located close to the tip of both arms intercalate between the base pairs accounting for the kinks (Rice et al. 1996; Rice 1997). Sequence specificity of IHF recognition is derived from indirect readout by shape recognition of the minor groove next to a negligible amount of hydrogen bonding (Rice 1997; Swinger and Rice 2004). Nevertheless, the contribution to sequence specificity is much higher for the IHF 
$\alpha$-arm extending more deeply into the minor groove than the $\beta$-arm (Rice et al. 1996). Interestingly, as derived from the co-crystal structure the Pro65 of the $\alpha$-arm adopts an exoconformation whereas the intercalating Pro64 of the $\beta$-subunit is crystallized as the endo-conformer.

Intercalation of proline (1) is of importance in the IHFinduced process of DNA bending. Therefore, other amino acids with higher sterical demand or conformational preorganization were investigated in order to examine the influence on dsDNA binding and bending. An aromatic side chain derived from phenylalanine (Phe, 2) was explored next to the cyclic amino acid 1,2,3,4-tetrahydroisoquinoline-3-carboxylic acid (Thi, 3) combining the properties of an aromatic and a cyclic amino acid side chain. Furthermore, the proline conformations found in the IHF/DNA co-crystal structure can be stabilized by fluorine (Barth et al. 2004; Hodges and Raines 2003; Renner et al. 2001; Shoulders et al. 2006; Kim et al. 2006), azide (Sonntag et al. 2006; Erdmann et al. 2009) or hydroxyl ring substituents (Lesarri et al. 2005) at C3 or C4. Especially, the highly polarized $\mathrm{C}-\mathrm{F}$ bond is suited to provide the endo-conformation in case of (4S)-fluoroproline ((4S)FPro, 4) and the exo-conformation in case of (4R)-fluoroproline ((4R)-FPro, 5) (Fig. 2) (Horng and Raines 2006; Naduthambi and Zondlo 2006). The possibility to generate conformationally constrained proline rings was used to investigate the influence of various proline derivatives incorporated in the $\beta$-sheet loop structure of the IHF $\alpha$-arm. The (4S)-FPro and (4R)-FPro derivatives were compared to peptides containing 3,4-dehydroproline (Dh-Pro, 6) (Benedetti et al. 1981; Fisher et al. 1978), and the $\alpha$-methylproline ( $\alpha$ Me-Pro, 7) (Welsh et al. 1992; Hinds et al. 1991) with respect to binding and intercalation in dsDNA (Fig. 2).

The system used for investigation of DNA interaction of the respective proline derivatives was based on an IHF mimicking peptide 8 (Fig. 3) reported earlier (Liebler and Diederichsen 2004). A three generation lysine dendrimer was used to imitate the positively charged body of IHF providing a comparable amount of positive charges under

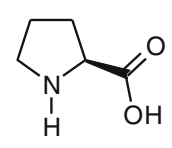

1

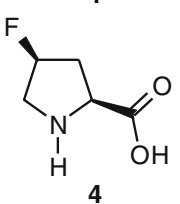

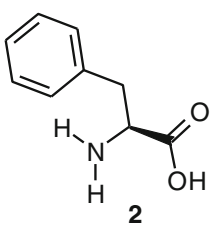
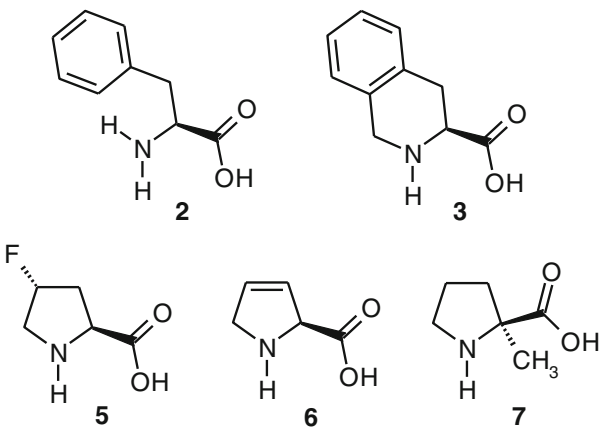

Fig. 2 Proline and derivatives that were incorporated into the $\beta$-sheet loop of peptide IHF-mimics representing the intercalating proline in the $\alpha$-arm of IHF

physiological conditions. The dendrimer is connected with the minor groove recognition motive by a glycine heptapeptide. As mimic for the IHF $\alpha$-arm a cyclopeptide was chosen in order to retain the $\beta$-sheet hairpin conformation. A sequence of ten amino acids around the intercalating proline (-GRNP65KTGEDI-) was used in homology to the IHF $\alpha$-arm. Elongation by the two amino acids, diaminopropionic acid (Dap) and D-Pro allow for side chain attachment and provide the template for $\beta$-turn formation. The resulting cyclopeptide is likely to retain the required $\beta$-sheet loop conformation for minor groove recognition. Binding studies performed by gel electrophoresis reveal affinity of the IHF mimic $\mathbf{8}$ to dsDNA containing the $\lambda$ phage $\mathrm{H}^{\prime}$-binding site and also a tendency for bending dsDNA.

Based on IHF mimicking peptide $\mathbf{8}$, the influence of the aromatic side chains at the proline intercalation site and of proline derivatives with defined conformation were investigated. Intercalation of the IHF $\alpha$-arm mimics in dsDNA were examined preparing derivatives of construct $\mathbf{8}$ varying the intercalating proline to Phe (2), Thi (3), (4S)-FPro (4), (4R)-FPro (5), Dh-Pro (6) and $\alpha$ Me-Pro (7). For preparation of the IHF mimics a modular approach was used connecting the dendrimer/linker construct to the respective cyclopeptide. Binding of dsDNA was investigated by gel
Fig. 1 Co-crystal strucutre of the IHF protein domain bound to the 35 bp dsDNA $\mathrm{H}^{\prime}$-binding site and expanded view of the $\alpha$-subunit with the proline residue intercalating between nucleobases thymine 37 and 38 (Rice et al. 1996)

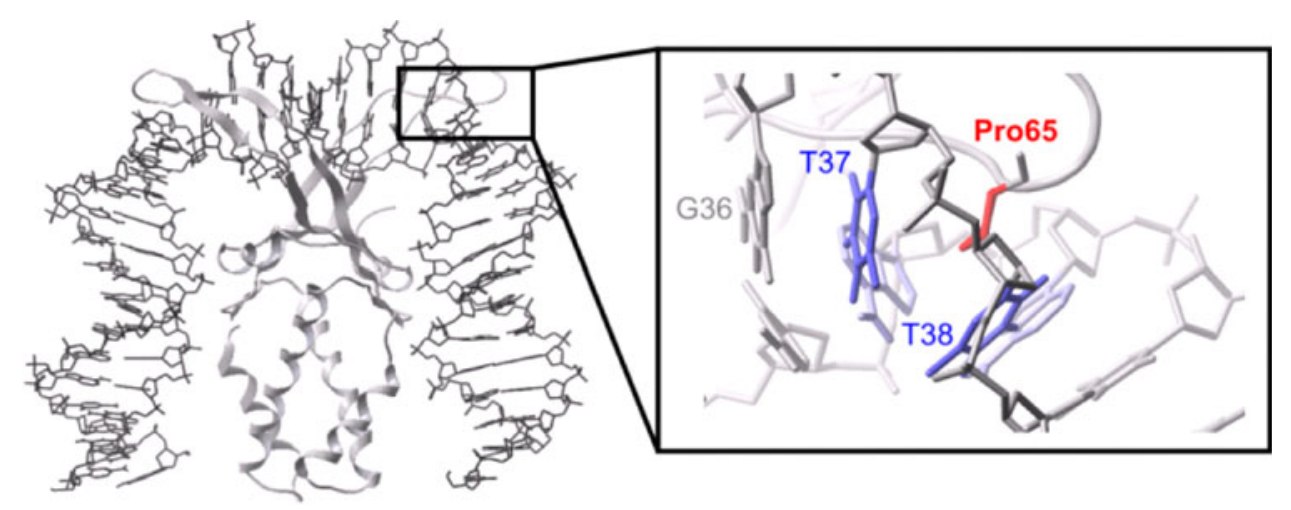


Fig. 3 Representation of peptide $\mathbf{8}$ designed for mimicking the native DNAbinding IHF domain

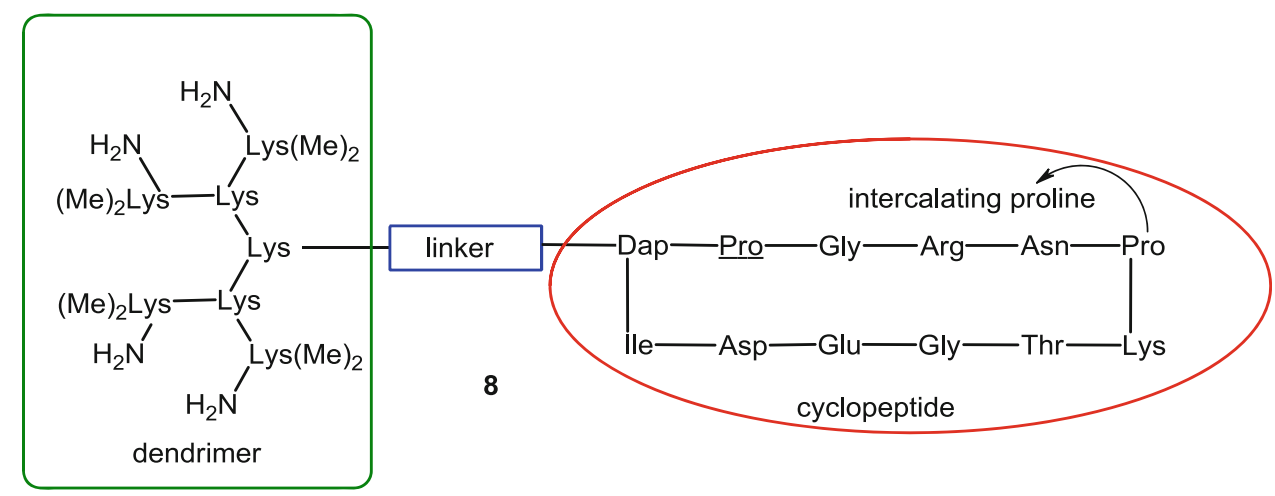

electrophoresis and fluorescence resonance energy transfer (FRET).

\section{Materials and methods}

General remarks

All reagents were of analytical grade and used without further purification. Solvents were of the highest grade available; dry solvents were stored over molecular sieves (4 ̊). Glass equipment used for reactions under inert atmosphere was flame dried before use. ESI-MS data were obtained with a Finnigan (type LGC or TSQ 7000) spectrometer, high resolution spectra were obtained with a Bruker (FT ICR MS, Apex-Q IV 7T) mass spectrometer. For automated SPPS a peptide synthesizer 433 A from Applied Biosystems was used. The FastMoc $0.10 \mathrm{mmol}$ or FastMoc $0.25 \mathrm{mmol}$ (amount of resin) Fmoc standard protocol in a 8 or $41 \mathrm{~mL}$ reaction vessel were used. HPLC analyses were performed on a Pharmacia Biotech Äkta Basic (pump type P-900, variable wavelength detector) or a JASCO HPLC (pump type PU-2080 plus, variable wavelength detector). UV absorption was detected at $215 \mathrm{~nm}$ with a linear gradient of A $\left(0.1 \%\right.$ TFA in $\left.\mathrm{H}_{2} \mathrm{O}\right)$ to $\mathrm{B}(0.1 \%$ TFA in $\mathrm{MeCN})$ for the $J A S C O$ HPLC or A $\left(0.1 \%\right.$ TFA in $\left.\mathrm{H}_{2} \mathrm{O}\right)$ to $\mathrm{B}^{\prime}(0.1 \%$ TFA in $\mathrm{MeCN} / \mathrm{H}_{2} \mathrm{O}$ 8:2) or $\mathrm{B}^{\prime \prime}\left(0.1 \%\right.$ TFA in $\mathrm{MeCN} / \mathrm{H}_{2} \mathrm{O}$ 9:1) for Pharmacia Äkta Basic. Peptides were analyzed using a YMC J'sphere column ODS-H80, RP-C18, $250 \times 4.6 \mathrm{~mm}, 4 \mu \mathrm{m}$, $80 \AA$ or a JASCO Reprosil, RP-C4, $250 \times 4 \mathrm{~mm}, 5 \mu \mathrm{m}$, $80 \AA$ with a flow rate of $1 \mathrm{~mL} \mathrm{~min}^{-1}$. Purification was performed with a JASCO Reprosil, RP-C4, $250 \times 10 \mathrm{~mm}$, $5 \mu \mathrm{m}, 80 \AA$ with a flow rate of $3 \mathrm{~mL} \mathrm{~min}^{-1}$ or $Y M C$ J' sphere column ODS-H80, RP-C18, $250 \times 20 \mathrm{~mm}, 4 \mu \mathrm{m}$, $80 \AA$ with a flow rate of $10 \mathrm{~mL} \mathrm{~min}^{-1}$. The fractions containing the desired product were collected and lyophilized. Fluorescence measurements were taken on a JASCO FP-6200 instrument. The 55 bp FRET DNA containing the $\mathrm{H}^{\prime}$-binding site was commercially available.
H-Dap(Alloc)D-ProGlyArg(Pbf)Asn(Trt)XPLys(Boc) $\mathrm{Thr}(\mathrm{tBu}) \mathrm{GlyGlu}(\mathrm{tBu}) \mathrm{Asp}(\mathrm{tBu}) \mathrm{Ile}-\mathrm{OH}$ (10a-f)

Peptides 10a-f were synthesized by automated SPPS on isoleucine preloaded 2-chlorotrityl resin according to standard Fmoc chemistry protocols (10a, c, d FastMoc $0.10 \mathrm{mmol}, \mathbf{1 0 b}$, e, f FastMoc $0.25 \mathrm{mmol}$ ). Double coupling was performed for the respective $\alpha$-methylproline derivative. The peptide was cleaved from the resin with $30 \%$ HFIP in DCM $(5 \mathrm{~mL})$ for $45 \mathrm{~min}$ at r.t. The crude product 10a-f was precipitated in cold ether $(5 \mathrm{~mL})$ and purified by reverse phase HPLC to give the linear peptide as a white solid. 10a Yield: $63.6 \mathrm{mg}, 29 \%$. HPLC $\left(50 \rightarrow 90 \% \mathrm{~B}^{\prime \prime}\right.$ in $\left.30 \mathrm{~min}\right) t_{\mathrm{R}}: 26.8 \mathrm{~min}$. ESI-MS $\mathrm{m} / \mathrm{z}$ : $1,106(100 \%)[\mathrm{M}+2 \mathrm{Na}]^{2+}, 1,095(80)[\mathrm{M}+\mathrm{H}+\mathrm{Na}]^{2+}$. HR-MS (ESI): $\left[\mathrm{C}_{109} \mathrm{H}_{158} \mathrm{~N}_{18} \mathrm{O}_{26} \mathrm{~S}\right][\mathrm{M}+2 \mathrm{H}]^{2+}$ calcd. 1,083.5652 found 1,083.5650. 10b Yield: $442 \mathrm{mg}, 81 \%$. HPLC $\left(50 \rightarrow 100 \% \mathrm{~B}^{\prime}\right.$ in $\left.30 \mathrm{~min}\right) t_{\mathrm{R}}: 29.9 \mathrm{~min}$. ESI-MS $m / z: 2,200(100 \%)[\mathrm{M}+\mathrm{Na}]^{+}, 2,179(75)[\mathrm{M}+\mathrm{H}]^{+}$. HRMS (ESI): $\quad\left[\mathrm{C}_{110} \mathrm{H}_{158} \mathrm{~N}_{18} \mathrm{O}_{26} \mathrm{~S}\right] \quad[\mathrm{M}+2 \mathrm{H}]^{2+}$ calcd. 1,089.5652 found 1,089.5655. 10c Yield: $75.5 \mathrm{mg}, 36 \%$. HPLC $(60 \rightarrow 100 \% \mathrm{~B}$ in $30 \mathrm{~min}) t_{\mathrm{R}}: 18.4 \mathrm{~min}$. ESIMS $m / z: 2,133 \quad(100 \%) \quad[\mathrm{M}+\mathrm{H}]^{+}, \quad 1,079 \quad(55)$ $[\mathrm{M}+\mathrm{H}+\mathrm{Na}]^{2+}$. HR-MS (ESI): $\left[\mathrm{C}_{105} \mathrm{H}_{155} \mathrm{~N}_{18} \mathrm{O}_{26} \mathrm{SF}\right]$ $[\mathrm{M}+2 \mathrm{H}]^{2+}$ calcd. 1,067.55268 found 1,067.55273. 10d Yield: $55.5 \mathrm{mg}, 26 \%$. HPLC $(60 \rightarrow 100 \% \mathrm{~B}$ in $30 \mathrm{~min}) t_{\mathrm{R}}$ : $17.8 \mathrm{~min}$. ESI-MS $m / z: 2,133(100 \%)[\mathrm{M}+\mathrm{H}]^{+}, 2,131$ (78) $[\mathrm{M}-\mathrm{H}]^{-}, 1,079$ (100) $[\mathrm{M}+\mathrm{H}+\mathrm{Na}]^{2+}$. HR-MS (ESI): $\left[\mathrm{C}_{105} \mathrm{H}_{155} \mathrm{~N}_{18} \mathrm{O}_{26} \mathrm{SF}\right][\mathrm{M}+2 \mathrm{H}]^{2+}$ calcd. 1,067 . 55268 found 1,067.55248. 10e Yield: $391 \mathrm{mg}, 74 \%$. HPLC $\left(60 \rightarrow 100 \% \mathrm{~B}^{\prime}\right.$ in $\left.30 \mathrm{~min}\right) t_{\mathrm{R}}: 23.5 \mathrm{~min}$. ESI-MS $m / z: 2,114(92 \%)[\mathrm{M}+\mathrm{H}]^{+}, 2,112(100)[\mathrm{M}-\mathrm{H}]^{-}$. HR-MS (ESI): $\left[\mathrm{C}_{105} \mathrm{H}_{154} \mathrm{~N}_{18} \mathrm{O}_{26} \mathrm{~S}\right][\mathrm{M}+2 \mathrm{H}]^{2+}$ calcd. 1,057.54957 found 1,057.54894. 10f Yield: $111 \mathrm{mg}, 26 \%$. HPLC $(60 \rightarrow 100 \% \mathrm{~B}$ in $30 \mathrm{~min}) t_{\mathrm{R}}: 15.9 \mathrm{~min}$. ESI-MS $m / z: 2,152(80 \%)[\mathrm{M}+\mathrm{Na}]^{+}, 2,130(100)[\mathrm{M}+\mathrm{H}]^{+}$, 1,066 (100) $[\mathrm{M}+2 \mathrm{H}]^{2+}$. HR-MS (ESI): $\left[\mathrm{C}_{106} \mathrm{H}_{158} \mathrm{~N}_{18} \mathrm{O}_{26} \mathrm{~S}\right][\mathrm{M}+2 \mathrm{H}]^{2+}$ calcd. 1,065.56522 found $1,065.56507$. 
Cyclo[Dap(Alloc)D-ProGlyArg(Pbf)Asn(Trt)

XPLys(Boc)Thr(tBu)GlyGlu(tBu)Asp(tBu)Ile] (11a-f)

Under inert gas atmosphere the respective linear precursor 10a-f was dissolved in DCM/DMF (9:1) until a $10^{-3}-10^{-4}$ M solution was reached. DIC (10 equiv), HOAt (1 equiv, $0.5 \mathrm{~mol} / \mathrm{L}$ in DMF) and NMM (3 equiv) were added and the reaction mixture was stirred at r.t. for 2 days. After removal of solvents the residue was dissolved in $\mathrm{MeOH}(1 \mathrm{~mL}$ for $10 \mathrm{mg}$ peptide) and purified by reverse phase HPLC. 11a Yield: $60 \%$. HPLC $\left(80 \rightarrow 100 \% \mathrm{~B}^{\prime \prime}\right.$ in $\left.30 \mathrm{~min}\right) t_{\mathrm{R}}: 21.9 \mathrm{~min}$. ESI-MS $m / z: 1,097(100 \%)[\mathrm{M}+2 \mathrm{Na}]^{2+}, 1,086$ (10) $[\mathrm{M}+\mathrm{H}+\mathrm{Na}]^{2+}$. HR-MS (ESI): $\left[\mathrm{C}_{109} \mathrm{H}_{155} \mathrm{~N}_{18} \mathrm{O}_{25} \mathrm{SNa}\right]$ $[\mathrm{M}+\mathrm{H}+\mathrm{Na}]^{2+}$ calcd. 1,085.5509 found 1,085.5503, $\left[\mathrm{C}_{109} \mathrm{H}_{156} \mathrm{~N}_{18} \mathrm{O}_{25} \mathrm{~S}\right][\mathrm{M}+2 \mathrm{H}]^{2+}$ calcd. 1,074.5599 found 1,074.5609. 11b Yield: 63\%. HPLC $(70 \rightarrow 100 \% \mathrm{~B}$ in $30 \mathrm{~min}) \quad t_{\mathrm{R}}: 21.5 \mathrm{~min}$. ESI-MS $\mathrm{m} / \mathrm{z}: \quad 2,160 \quad(100 \%)$ $[\mathrm{M}+\mathrm{H}]^{+}$. HR-MS (ESI): $\left[\mathrm{C}_{110} \mathrm{H}_{156} \mathrm{~N}_{18} \mathrm{O}_{25} \mathrm{~S}\right][\mathrm{M}+2 \mathrm{H}]^{2+}$ calcd. 1,080.5599 found 1,080.5600. 11c Yield: 58\%. HPLC $(60 \rightarrow 100 \% \mathrm{~B}$ in $30 \mathrm{~min}) t_{\mathrm{R}}: 21.9 \mathrm{~min}$. ESI-MS $\mathrm{m} / \mathrm{z}: 2,139$ $(100 \%), \quad[\mathrm{M}+\mathrm{Na}]^{+} . \quad \mathrm{HR}-\mathrm{MS} \quad(\mathrm{ESI}): \quad\left[\mathrm{C}_{105} \mathrm{H}_{152} \mathrm{FN}_{18}\right.$ $\left.\mathrm{O}_{25} \mathrm{SNa}\right][\mathrm{M}+\mathrm{H}+\mathrm{Na}]^{2+}$ calcd. 1,069.53837 found 1,069.53814, $\quad\left[\mathrm{C}_{105} \mathrm{H}_{153} \mathrm{FN}_{18} \mathrm{O}_{25} \mathrm{~S}\right] \quad[\mathrm{M}+2 \mathrm{H}]^{2+}$ calcd. 1,058.5470 found 1,058.54653. 11d Yield: $86 \%$. HPLC $(60 \rightarrow 100 \% \mathrm{~B}$ in $30 \mathrm{~min}) t_{\mathrm{R}}: 23.5 \mathrm{~min}$. ESI-MS $\mathrm{m} / z: 2,139$ $(100 \%)[\mathrm{M}+\mathrm{Na}]^{+}, 1,081$ (70) $[\mathrm{M}+2 \mathrm{Na}]^{2+}$. HR-MS (ESI): $\left[\mathrm{C}_{105} \mathrm{H}_{152} \mathrm{FN}_{18} \mathrm{O}_{25} \mathrm{SNa}\right][\mathrm{M}+\mathrm{H}+\mathrm{Na}]^{2+}$ calcd. $1,069.53837$ found 1,069.53926, $\left[\mathrm{C}_{105} \mathrm{H}_{153} \mathrm{FN}_{18} \mathrm{O}_{25} \mathrm{~S}\right]$ $[\mathrm{M}+2 \mathrm{H}]^{2+}$ calcd. $1,058.5470$ found $1,058.54753$. 11e Yield: $64 \%$. HPLC $(60 \rightarrow 100 \%$ B in $30 \mathrm{~min}) t_{\mathrm{R}}: 28.5 \mathrm{~min}$. ESI-MS m/z: 2,119 (100\%) [M + Na ${ }^{+}, 2,093(20)[\mathrm{M}-\mathrm{H}]^{-}$. HR-MS (ESI): $\left[\mathrm{C}_{105} \mathrm{H}_{152} \mathrm{~N}_{18} \mathrm{O}_{25} \mathrm{~S}\right][\mathrm{M}+2 \mathrm{H}]^{2+}$ calcd. 1,048.54429 found 1,048.54429. 11f Yield: 66\%. HPLC $(60 \rightarrow 100 \% \mathrm{~B}$ in $30 \mathrm{~min}) t_{\mathrm{R}}: 15.9 \mathrm{~min}$. ESI-MS $\mathrm{m} / z: 2,135$ $(100 \%)[\mathrm{M}+\mathrm{Na}]^{+}$. HR-MS (ESI): $\left[\mathrm{C}_{106} \mathrm{H}_{156} \mathrm{~N}_{18} \mathrm{O}_{25} \mathrm{~S}\right]$ $[\mathrm{M}+2 \mathrm{H}]^{2+}$ calcd. $1,056.55994$ found $1,056.56065$.

\section{Cyclo[Dapd-ProGlyArg(Pbf)Asn(Trt)XPLys(Boc) \\ Thr(tBu)GlyGlu(tBu)Asp(tBu)Ile] (12a-f)}

The respective cyclic peptide 11a-f was dissolved in dry DMF (1 mL for $10 \mathrm{mg}$ peptide) under inert gas atmosphere. $\mathrm{Me}_{2} \mathrm{NH} \cdot \mathrm{BH}_{3}$ (40 equiv) and $\mathrm{Pd}\left(\mathrm{PPh}_{3}\right)_{4}$ (0.1 equiv) were added and the reaction mixture was stirred at r.t. for $4 \mathrm{~h}$. After removing the solvent, the crude product $\mathbf{1 2}$ was purified via reverse phase HPLC. 12a Yield: 71\%. HPLC $\left(80 \rightarrow 100 \% \mathrm{~B}^{\prime}\right.$ in $\left.30 \mathrm{~min}\right) t_{\mathrm{R}}: 29.1 \mathrm{~min}$. ESI-MS $\mathrm{m} / z: 2,064$ $(100 \%) \quad[\mathrm{M}+\mathrm{H}]^{+}$. HR-MS (ESI): $\left[\mathrm{C}_{105} \mathrm{H}_{152} \mathrm{~N}_{18} \mathrm{O}_{23} \mathrm{~S}\right]$ $[\mathrm{M}+2 \mathrm{H}]^{2+}$ calcd. 1,032.5494 found 1,032.5494. 12b Yield: $38 \%$. HPLC ( $50 \rightarrow 100 \%$ B in $30 \mathrm{~min}) t_{\mathrm{R}}: 20.4 \mathrm{~min}$. ESI-MS $m / z: 2,075(20 \%)[\mathrm{M}+\mathrm{H}]^{+}$. HR-MS (ESI): $\left[\mathrm{C}_{106} \mathrm{H}_{151} \mathrm{~N}_{18} \mathrm{O}_{23} \mathrm{SNa}\right][\mathrm{M}+\mathrm{H}+\mathrm{Na}]^{2+}$ calcd. 1,049.5404 found 1,049.5402, $\left[\mathrm{C}_{106} \mathrm{H}_{152} \mathrm{~N}_{18} \mathrm{O}_{23} \mathrm{~S}\right][\mathrm{M}+2 \mathrm{H}]^{2+}$ calcd.
1,038.5494 found 1,038.5497. 12c Yield: $35 \%$. HPLC $\left(60 \rightarrow 100 \% \mathrm{~B}^{\prime}\right.$ in $\left.30 \mathrm{~min}\right) t_{\mathrm{R}}: 25.7 \mathrm{~min}$. ESI-MS $\mathrm{m} / z: 2,032$ $(100 \%)[\mathrm{M}+\mathrm{H}]^{+}, 2,030 \quad(76)[\mathrm{M}-\mathrm{H}]^{-}, 1,028 \quad(100)$ $[\mathrm{M}+\mathrm{H}+\mathrm{Na}]^{2+}$. HR-MS (ESI): $\left[\mathrm{C}_{101} \mathrm{H}_{149} \mathrm{FN}_{18} \mathrm{O}_{23} \mathrm{~S}\right]$ $[\mathrm{M}+2 \mathrm{H}]^{2+}$ calcd. $1,016.53648$ found $1,016.53634 .12 \mathrm{~d}$ Yield: $28 \%$. HPLC $\left(60 \rightarrow 100 \% \mathrm{~B}^{\prime}\right.$ in $\left.30 \mathrm{~min}\right) t_{\mathrm{R}}: 23.1 \mathrm{~min}$. ESI-MS $m / z: 2,031(100 \%)[\mathrm{M}+\mathrm{H}]^{+}, 2,029(92)[\mathrm{M}-\mathrm{H}]^{-}$, $1,028(100)[\mathrm{M}+\mathrm{H}+\mathrm{Na}]^{2+}, 1,017$ (12) $[\mathrm{M}+2 \mathrm{H}]^{2+}$. HR-MS (ESI): $\left[\mathrm{C}_{101} \mathrm{H}_{149} \mathrm{FN}_{18} \mathrm{O}_{23} \mathrm{~S}\right][\mathrm{M}+2 \mathrm{H}]^{2+}$ calcd. 1,016.53648 found 1,016.53634. 12e Yield: $66 \%$. HPLC $(60 \rightarrow 100 \% \mathrm{~B}$ in $30 \mathrm{~min}) t_{\mathrm{R}}: 20.1 \mathrm{~min}$. ESI-MS $\mathrm{m} / z: 2,012$ $(100 \%) \quad[\mathrm{M}+\mathrm{H}]^{+}, 2,011$ (52) $[\mathrm{M}-\mathrm{H}]^{-}, 1,018$ (100) $[\mathrm{M}+\mathrm{H}+\mathrm{Na}]^{2+} . \quad$ HR-MS (ESI): $\left[\mathrm{C}_{101} \mathrm{H}_{148} \mathrm{~N}_{18} \mathrm{O}_{23} \mathrm{~S}\right]$ $[\mathrm{M}+2 \mathrm{H}]^{2+}$ calcd. $1,006.53372$ found $1,006.53319$. 12f Yield: $48 \%$. HPLC $(60 \rightarrow 100 \% \mathrm{~B}$ in $30 \mathrm{~min}) t_{\mathrm{R}}: 17.3 \mathrm{~min}$. ESI-MS $m / z: 2,050 \quad(19 \%) \quad[\mathrm{M}+\mathrm{Na}]^{+}, \quad 2,028 \quad(100)$ $[\mathrm{M}+\mathrm{H}]^{+}, 1,015(78)[\mathrm{M}+2 \mathrm{H}]^{2+}, 960(31)[\mathrm{M}+4 \mathrm{H}]^{4+}$. HR-MS (ESI): $\left[\mathrm{C}_{102} \mathrm{H}_{152} \mathrm{~N}_{18} \mathrm{O}_{23} \mathrm{~S}\right][\mathrm{M}+2 \mathrm{H}]^{2+}$ calcd. $1,014.54937$ found $1,014.54850$.

[Boc-Lys $\left.\left(\mathrm{Me}_{2}\right)\right]_{4} \mathrm{Lys}_{2} \mathrm{LysGly}_{7}-\mathrm{cyclo}$ [DapD-ProGlyArg (Pbf)Asn(Trt)XPLys(Boc)Thr(tBu)Gly $\mathrm{Glu}(\mathrm{tBu}) \mathrm{Asp}(\mathrm{tBu})]$ (13a-f)

Under inert gas atmosphere a solution of dendrimer 9 (2.5 equiv), DIC ( 8 equiv), HOAt ( 3 equiv) and NMM ( 3 equiv) in dry DMF ( $1 \mathrm{~mL}$ for $50 \mathrm{mg}$ dendrimer) was added to the cyclopeptides 12a, b dissolved in dry DMF $(1 \mathrm{~mL}$ for $20 \mathrm{mg}$ cyclopeptide). The reaction mixtures were stirred at r.t. for $7 \mathrm{~h}$. Reverse phase HPLC afforded 13a, $\mathbf{b}$ as a white solid. 13a Yield: $49 \%$. HPLC $\left(50 \rightarrow 90 \% \mathrm{~B}^{\prime}\right.$ in $\left.30 \mathrm{~min}\right) t_{\mathrm{R}}$ : $20.6 \mathrm{~min}$. ESI-MS m/z: 1,936 (100\%) $[\mathrm{M}+4 \mathrm{H}]^{4+}, 1,292$ (16) $[\mathrm{M}+3 \mathrm{H}]^{3+}$. HR-MS (ESI): $\left[\mathrm{C}_{189} \mathrm{H}_{307} \mathrm{~N}_{39} \mathrm{O}_{45} \mathrm{~S}\right]$ $[\mathrm{M}+4 \mathrm{H}]^{4+}$ calcd. 968.8158 found 968.8156 . 13b Yield: $66 \%$. HPLC $\left(50 \rightarrow 100 \% \mathrm{~B}^{\prime}\right.$ in $\left.30 \mathrm{~min}\right) t_{\mathrm{R}}: 17.6 \mathrm{~min}$. ESIMS $m / z: 1,296(25 \%)[\mathrm{M}+3 \mathrm{H}]^{3+}, 972(100)[\mathrm{M}+4 \mathrm{H}]^{4+}$. HR-MS (ESI): $\left[\mathrm{C}_{190} \mathrm{H}_{306} \mathrm{~N}_{39} \mathrm{O}_{45} \mathrm{~S}\right][\mathrm{M}+3 \mathrm{H}]^{3+}$ calcd. $1,295.4186$ found 1,295.4186, $\left[\mathrm{C}_{190} \mathrm{H}_{307} \mathrm{~N}_{39} \mathrm{O}_{45} \mathrm{~S}\right]$ $[\mathrm{M}+4 \mathrm{H}]^{4+}$ calcd. 971.8158 found 971.8155 . Under inert gas atmosphere dendrimer 9 ( 2 equiv) and the respective cyclopeptide 12c-f (1 equiv) were dissolved in dry DMF $(500 \mu \mathrm{L})$. Then DIC ( 8 equiv), HOAt ( 7.9 equiv, $0.5 \mathrm{~mol} / \mathrm{L}$ in DMF) and NMM (10 equiv) were added. The reaction mixture was stirred at r.t. for 2 days, then the solvent was removed in vacuum. The residue was purified by reverse phase HPLC. 13c Yield: 58\%. HPLC $(20 \rightarrow 80 \% \mathrm{~B}$ in $30 \mathrm{~min}) \quad t_{\mathrm{R}}: 23.5 \mathrm{~min}$. ESI-MS $\mathrm{m} / \mathrm{z}: \quad 3,840 \quad(100 \%)$ $[\mathrm{M}+\mathrm{H}]^{+}, \quad 961 \quad$ (69) $[\mathrm{M}+4 \mathrm{H}]^{4+}$. HR-MS (ESI): $\left[\mathrm{C}_{185} \mathrm{H}_{304} \mathrm{FN}_{39} \mathrm{O}_{45} \mathrm{~S}\right][\mathrm{M}+4 \mathrm{H}]^{4+}$ calcd. 960.80953 found 960.80896, $\quad\left[\mathrm{C}_{185} \mathrm{H}_{305} \mathrm{FN}_{39} \mathrm{O}_{45} \mathrm{~S}\right] \quad[\mathrm{M}+5 \mathrm{H}]^{5+}$ calcd. 768.84908 found 768.84901. 13d Yield: 63\%. HPLC $\left(20 \rightarrow 80 \% \mathrm{~B}\right.$ in $30 \mathrm{~min}$ ) $t_{\mathrm{R}}: 21.3 \mathrm{~min}$. ESI-MS $\mathrm{m} / z: 3,840$ $(100 \%)[\mathrm{M}+\mathrm{H}]^{+}, 961(57)[\mathrm{M}+4 \mathrm{H}]^{4+}$. HR-MS (ESI) 
$\left[\mathrm{C}_{185} \mathrm{H}_{302} \mathrm{FN}_{39} \mathrm{O}_{45} \mathrm{~S}\right][\mathrm{M}+2 \mathrm{H}]^{2+}$ calcd. 960.80953 found 960.80938 . 13e Yield: $33 \%$. HPLC $(20 \rightarrow 80 \% \mathrm{~B}$ in $30 \mathrm{~min})$ $t_{\mathrm{R}}: 20.7 \mathrm{~min}$, ESI-MS $m / z: 3,842(16 \%)[\mathrm{M}+\mathrm{Na}]^{+}, 3,820$ (100) $[\mathrm{M}+\mathrm{H}]^{+}$. HR-MS (ESI): $\left[\mathrm{C}_{185} \mathrm{H}_{303} \mathrm{~N}_{39} \mathrm{O}_{45} \mathrm{~S}\right]$ $[\mathrm{M}+4 \mathrm{H}]^{4+}$ calcd. 955.80798 found $955.80810 .13 f$ Yield: $63 \%$. HPLC $(20 \rightarrow 80 \% \mathrm{~B}$ in $30 \mathrm{~min}) t_{\mathrm{R}}: 22.3 \mathrm{~min}$. ESI-MS $m / z: 3,858(85 \%)[\mathrm{M}+\mathrm{Na}]^{+}, 3,836(30)[\mathrm{M}+\mathrm{H}]^{+}$. HRMS (ESI): $\quad\left[\mathrm{C}_{186} \mathrm{H}_{307} \mathrm{~N}_{39} \mathrm{O}_{45} \mathrm{~S}\right] \quad[\mathrm{M}+4 \mathrm{H}]^{4+}$ calcd. 959.81580 found 959.81562 .

$\left[\mathrm{Lys}\left(\mathrm{Me}_{2}\right)\right]_{4} \mathrm{Lys}_{2} \mathrm{LysGly}_{7}$-cyclo[DapD-

ProGlyArgAsnXPLysThrGlyGluAspIle] (14a-f)

The respective coupling product 13a-f was dissolved in 95\% aq. TFA and stirred for $90 \mathrm{~min}$ at r.t. After removing the TFA and purification via reverse phase HPLC the IHF mimic 14a-f was obtained. 14a Yield: 76\%. HPLC $(5 \rightarrow 40 \%$ $\mathrm{B}^{\prime}$ in $\left.30 \mathrm{~min}\right) t_{\mathrm{R}}: 17.5 \mathrm{~min}$. ESI-MS $\mathrm{m} / \mathrm{z}: 1,356(100 \%)$ $[\mathrm{M}+2 \mathrm{H}]^{2+}, 904$ (75) $[\mathrm{M}+3 \mathrm{H}]^{3+}$. HR-MS (ESI): $\left[\mathrm{C}_{120} \mathrm{H}_{215} \mathrm{~N}_{39} \mathrm{O}_{32}\right][\mathrm{M}+6 \mathrm{H}]^{6+}$ calcd. 452.4394 found 452.4394. 14b Yield: $76 \%$. HPLC ( $\rightarrow 40 \% \mathrm{~B}^{\prime}$ in $\left.30 \mathrm{~min}\right)$ $t_{\mathrm{R}}: 14.7 \mathrm{~min}$. ESI-MS m/z: $908(100 \%)[\mathrm{M}+3 \mathrm{H}]^{3+}$. HRMS (ESI): $\left[\mathrm{C}_{121} \mathrm{H}_{213} \mathrm{~N}_{39} \mathrm{O}_{32}\right][\mathrm{M}+4 \mathrm{H}]^{4+}$ calcd. 681.1554 found 681.1554, $\left[\mathrm{C}_{121} \mathrm{H}_{214} \mathrm{~N}_{39} \mathrm{O}_{32}\right][\mathrm{M}+5 \mathrm{H}]^{5+}$ calcd. 545.1258 found 545.1259. 14c Yield: 86\%. HPLC $\left(3 \rightarrow 40 \% \mathrm{~B}\right.$ in $30 \mathrm{~min}$ ) $t_{\mathrm{R}}: 6.9 \mathrm{~min}$. ESI-MS $\mathrm{m} / z: 2,678$ $(100 \%) \quad[\mathrm{M}+\mathrm{H}]^{+}, 670 \quad(15)[\mathrm{M}+4 \mathrm{H}]^{4+}, \quad 536 \quad(54)$ $[\mathrm{M}+5 \mathrm{H}]^{5+}, 447$ (35) $[\mathrm{M}+6 \mathrm{H}]^{6+}$. HR-MS (ESI): $\left[\mathrm{C}_{116} \mathrm{H}_{211} \mathrm{FN}_{39} \mathrm{O}_{32}\right][\mathrm{M}+5 \mathrm{H}]^{5+}$ calcd. 536.32078 found 536.32080. 14d Yield: $84 \%$. HPLC $(3 \rightarrow 40 \%$ B in $30 \mathrm{~min}$ ) $t_{\mathrm{R}}: 7.2$ min. ESI-MS $m / z: 2,678(100 \%)[\mathrm{M}+\mathrm{H}]^{+}, 893(4)$ $[\mathrm{M}+3 \mathrm{H}]^{3+}, 670(32)[\mathrm{M}+4 \mathrm{H}]^{4+}, 536(51)[\mathrm{M}+5 \mathrm{H}]^{5+}$, 447 (15) $[\mathrm{M}+6 \mathrm{H}]^{6+}$. HR-MS (ESI): $\left[\mathrm{C}_{116} \mathrm{H}_{210} \mathrm{FN}_{39} \mathrm{O}_{32}\right]$ $[\mathrm{M}+4 \mathrm{H}]^{4+}$ calcd. 670.14915 found $670.14919 .14 \mathrm{e}$ Yield: $76 \%$. HPLC $(3 \rightarrow 40 \% \mathrm{~B}$ in $30 \mathrm{~min}) t_{\mathrm{R}}: 17.7 \mathrm{~min}$. ESI-MS $\mathrm{m} / \mathrm{z}: 2,657(100 \%)[\mathrm{M}+\mathrm{H}]^{+}, 665(15)[\mathrm{M}+4 \mathrm{H}]^{4+}, 532$ $[\mathrm{M}+5 \mathrm{H}]^{5+}$. HR-MS (ESI): $\left[\mathrm{C}_{116} \mathrm{H}_{209} \mathrm{~N}_{39} \mathrm{O}_{32}\right][\mathrm{M}+4 \mathrm{H}]^{4+}$ calcd. 665.14760 found 665.14750, $\left[\mathrm{C}_{116} \mathrm{H}_{210} \mathrm{~N}_{39} \mathrm{O}_{32}\right]$ $[\mathrm{M}+5 \mathrm{H}]^{5+}$ calcd. 532.31953 found 532.31938. 14f Yield: $84 \%$. HPLC ( $3 \rightarrow 40 \% \mathrm{~B}$ in $30 \mathrm{~min}) t_{\mathrm{R}}: 5.7 \mathrm{~min}$. ESI-MS $m / z: 2674(100 \%)[\mathrm{M}+\mathrm{H}]^{+}, 669(24)[\mathrm{M}+4 \mathrm{H}]^{4+}, 536$ (53) $[\mathrm{M}+5 \mathrm{H}]^{5+}, 446(36)[\mathrm{M}+6 \mathrm{H}]^{6+}$. HR-MS (ESI): $\left[\mathrm{C}_{117} \mathrm{H}_{213} \mathrm{~N}_{39} \mathrm{O}_{32}\right][\mathrm{M}+4 \mathrm{H}]^{4+}$ calcd. 669.15542 found 669.15569, $\left[\mathrm{C}_{117} \mathrm{H}_{214} \mathrm{~N}_{39} \mathrm{O}_{32}\right][\mathrm{M}+5 \mathrm{H}]^{5+}$ calcd. 535. 52579 found 535.52595 .

\section{PCR}

PCR was carried out in a MWG Biotech thermal cycler Primus 96 Plus. $1 \mu \mathrm{L}$ template DNA, $1 \mu \mathrm{L}$ primer-up, $1 \mu \mathrm{L}$ primer down, $1 \mu \mathrm{L}$ dNTPs, $5 \mu \mathrm{L}$ Taq buffer and $40 \mu \mathrm{L}$ $\mathrm{H}_{2} \mathrm{O}$ were placed in small reaction tubes $(0.2-0.5 \mathrm{~mL})$ and were covered with a layer of $30 \mu \mathrm{L}$ chillout-wax. The following programs were accomplished: $3 \min 95^{\circ} \mathrm{C}$, $2 \mathrm{~min} 85^{\circ} \mathrm{C}$ Taq polymerase $(1 \mu \mathrm{L})$ was added, [1 min $95^{\circ} \mathrm{C}, 1 \min 50^{\circ} \mathrm{C}, 1 \min 72^{\circ} \mathrm{C}$ (30 repeats)]; $10 \min 72^{\circ} \mathrm{C}$. The PCR products were analyzed via $1 \%$ agarose gel electrophoresis. The generated DNA fragments were combined and 1/10 part by volume $7 \mathrm{M} \mathrm{NH}_{4} \mathrm{Ac}$ and three parts by volume $96 \% \mathrm{EtOH}$ were added to precipitate the DNA. After vortexing the probe was centrifuged $(2 \times 3 \mathrm{~min})$ and the supernatant was discarded. The resulting pellet was dried in a heating block at $42^{\circ} \mathrm{C}$ and resuspended in water. The DNA was cut out of a $1 \%$ agarose gel and isolated with a Prep EaseTM Gel Extraction Kit. The DNA concentration was determined with a photometer and the purity was analyzed via $1 \%$ agarose gel electrophoresis. Sequence primers: $\mathrm{H}^{\prime}$-middle up: 5'-CATGC ATCTG TCGCA GTAGG ACTCA CGACT GATCT AGTCG ACGTA GIIGTTT CTCGT TCAGC TTTTT TATAC-3'; $\mathrm{H}^{\prime}$-middle down: 5'-TCACA GTATC

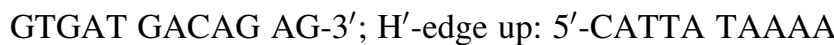
AAGCA TTGCT TATC-3'; $\mathrm{H}^{\prime}$-edge down: 5'-TCTGC AAGAC TCTAT GAGAA GC-3'; Sequence 200 bp DNA H'-middle: 5'-CATGC ATCTG TCGCA GTAGG ACTCA CGACT GATCT AGTCG ACGTA GGTTT CTCGT TCAGC TTTTT TATAC TAAGT TGGCA TTATA AAAAA GCATT GCTTA TCAAT TTGTT GCAAC GAACA GGTCA CTATC AGTCA AAATA AAATC ATTAT TTGAT TTCAA TTTTG TCCCA CTCCC TGCCT CTGTC ATCAC GATAC TGTGA-3'; Sequence 200 bp DNA H'-edge: 5'-CATTA TAAAA AAGCA TTGCT TATCA ATTTG TTGCA ACGAA CAGGT CACTA TCAGT CAAAA TAAAA TCATT ATTTG ATTTC AATTT TGTCC CACTC CCTGC CTCTG TCATC ACGAT ACTGT GATGC CATGG TGTCC GACTT ATGCC CGAGA AGATG TTGAG CAAAC TTATC GCTTA TCTGC TTCTC ATAGA GTCTT GCAGA-3'.

\section{Results and discussion}

Synthesis of IHF mimics with different intercalating amino acids

The preparation of IHF mimicking peptides followed the general approach described earlier for the convergent synthesis of mimic 8 (Liebler and Diederichsen 2004). The glycine heptamer linker with lysine dendrimer was built by automated SPPS on a glycine preloaded 2-chlorotrityl resin. The first two generations of the lysine dendrimer were added using Fmoc-Lys(Fmoc)-OH; the third lysine layer was attached applying Boc-Lys $(\mathrm{Me})_{2}-\mathrm{OH}$, which was obtained in two steps following literature procedures (Benoiton 1964; Hughes et al. 2007). After cleavage from 
the solid support the lysine dendrimer/linker building block was obtained as Boc-protected carboxylic acid 9 (Scheme 1). The cyclopeptides $\mathbf{1 2 a}-\mathbf{f}$ were also assembled by SPPS as linear dodecamer on an isoleucine preloaded 2-chlorotrityl resin. The proline derivatives 3-7 were Fmoc-protected as described in literature (Ruan et al. 1991; Albericio 2002) and incorporated in the respective peptide sequences. Cleavage of the peptides from solid support was accomplished under mild conditions using 30\% 1,1,1,3,3,3hexafluoro-isopropanol (HFIP) in dichloromethane (DCM) (Bollhagen et al. 1994).

The resulting side chain protected oligomers 10a-f were readily cyclized under dilution conditions in DCM/DMF adding $N, N^{\prime}$-diisopropylcarbodiimide (DIC) as coupling reagent together with 1-hydroxy-7-azabenzotriazole (HOAt) and $N$-methyl-morpholine (NMM) as base to yield cyclopeptides 11a-f.

Orthogonal removal of the Alloc protecting group (Fernandez-Forner et al. 2001) on the diaminopropionic acid (Dap) with $\mathrm{Pd}\left(\mathrm{PPh}_{3}\right)_{4}$ and $\mathrm{Me}_{2} \mathrm{NH} \cdot \mathrm{BH}_{3}$ as scavenger provided cyclopeptides $\mathbf{1 2 a}-\mathbf{f}$ ready for coupling with the dendrimer/linker construct 9 using DIC, HOAt and NMM activation in DMF. Finally, the resulting peptides 13a-f were deprotected at the lysine dendrimer and at the side chains of the cyclopeptides to provide the IHF mimicking constructs 14a-f.

DNA binding and bending of IHF analog 8

Based on the specificity of IHF mimic 8 for the $34 \mathrm{bp}$ $\mathrm{H}^{\prime}$-binding site (Swinger and Rice 2004) bending studies were performed using gel electrophoresis (Wu and Crothers 1984). 200 bp DNA double strands were used containing the $\mathrm{H}^{\prime}$-binding site either in a central $\left(\mathrm{H}^{\prime}\right.$-middle) or in a terminal position ( $\mathrm{H}^{\prime}$-edge). Specific binding and bending of one of the mimics leads to differently shaped DNA-peptide complexes. Binding to the $\mathrm{H}^{\prime}$-edge site results in a more linear shaped complex compared to $\mathrm{H}^{\prime}$-middle binding; the linear complex moves faster through an agarose gel (Wu and Crothers 1984). However, both complexes should be significantly retarded in comparison to dsDNA.

For preparation of $200 \mathrm{bp}$ DNA the $\mathrm{H}^{\prime}$-edge was amplified from the $502 \mathrm{bp}$ attP site ( $\lambda$ phage) together with 166 additional base pairs by PCR. In case of the $\mathrm{H}^{\prime}$-middle fragment, 83 extra base pairs on both sites $\left(5^{\prime}\right.$ and $\left.3^{\prime}\right)$ were required. Unfortunately, the $\mathrm{H} 2$-binding site is located only $37 \mathrm{bp}$ next to the $\mathrm{H}^{\prime}$-binding site. Using the same amplifying strategy as before the H2-binding site would also be present offering a second binding site. Therefore, elongated $5^{\prime}$-primers containing a 46 bp random sequence attachment together with the $37 \mathrm{bp}$ between the $\mathrm{H}^{\prime}$ and $\mathrm{H} 2$-binding sites were used for amplification.
Gel electrophoresis of the $200 \mathrm{bp}$ DNA with $\mathrm{H}^{\prime}$-edge or $\mathrm{H}^{\prime}$-middle positioning of the recognition sequence, respectively (lanes 2, 3 and 10, 11, Fig. 4), was performed adding 60 equivalents of IHF-mimic 8 (lanes 4 and 5) in Tris- $\mathrm{HCl}$ buffer $(10 \mathrm{~mm}$ Tris- $\mathrm{HCl}, 10 \mathrm{~mm}$ EDTA, $100 \mathrm{~mm} \mathrm{NaCl}, 1 \mathrm{~mm}$ dithiothreitol, $\mathrm{pH}$ 7.5) with an incubation time of $2 \mathrm{~h}$ at r.t. followed by $1 \mathrm{~h}$ at $4^{\circ} \mathrm{C}$. Both bands were significantly shifted whereas the higher bent complex was retarded (lane 4) with respect to the more linear adduct (lane 5). Bending of dsDNA induced by IHF mimic 8 is indicated; nevertheless, the difference in retardation is significantly lower compared to respective IHF/DNA complexes. The endonuclease Tsp509 is a restriction enzyme with AATT-site specificity to cleave in the $\mathrm{H}^{\prime}$-binding site. Nevertheless, the IHF mimic 8 inhibited DNA cleavage by $T s p 509$ (lanes 6 and 7); DNA was degraded by the enzyme in absence of peptide $\mathbf{8}$ (lanes 8 and 9). An interaction between the enzyme and peptide $\mathbf{8}$ is likely to prevent binding of peptide $\mathbf{8}$ at dsDNA and cleavage of DNA by the restriction enzyme.

IHF analogs with aromatic intercalator side chains

Phenylalanine (14a) and 1,2,3,4-tetrahydroisoquinoline3-carboxylic acid (14b) IHF analogs were prepared based on the hypothesis that a larger aromatic side chain might increase the interaction with the dsDNA base pair stack at the intercalator site. Gel electrophoresis of these peptides with the $200 \mathrm{bp}$ DNA containing the $\mathrm{H}^{\prime}$-edge and $\mathrm{H}^{\prime}$-middle recognition sequence were performed (Fig. 5).

Both peptides 14a and 14b provided DNA retardation indicating binding of the IHF analog. Nevertheless, a significant smearing of the bands revealed a loss of specificity in peptide binding. It was concluded that large intercalating side chains are in conflict with the recognition motif of the IHF $\alpha$-arm in the minor groove.

IHF-analogs with proline derived intercalator side chains

Since there seems to be a size restriction of the intercalating unit, the contribution of the proline residues in the IHF arms was further investigated with respect to the proline ring conformation. Since the co-crystal structure of IHF with dsDNA indicates an exo-Pro65 conformation in the $\alpha$-arm and an endo-Pro64 in the $\beta$-arm (Fig. 6), the conformation might be of significant importance for recognition. Electronegative substituents of the proline ring result in a preferred endo or exo-Pro conformation based on stereoelectronic effects (Barth et al. 2004; Hodges and Raines 2003; Sonntag et al. 2006; Erdmann et al. 2009; Lesarri et al. 2005; Horng and Raines 2006; Naduthambi and Zondlo 2006). The influence of the 4-fluoroproline 

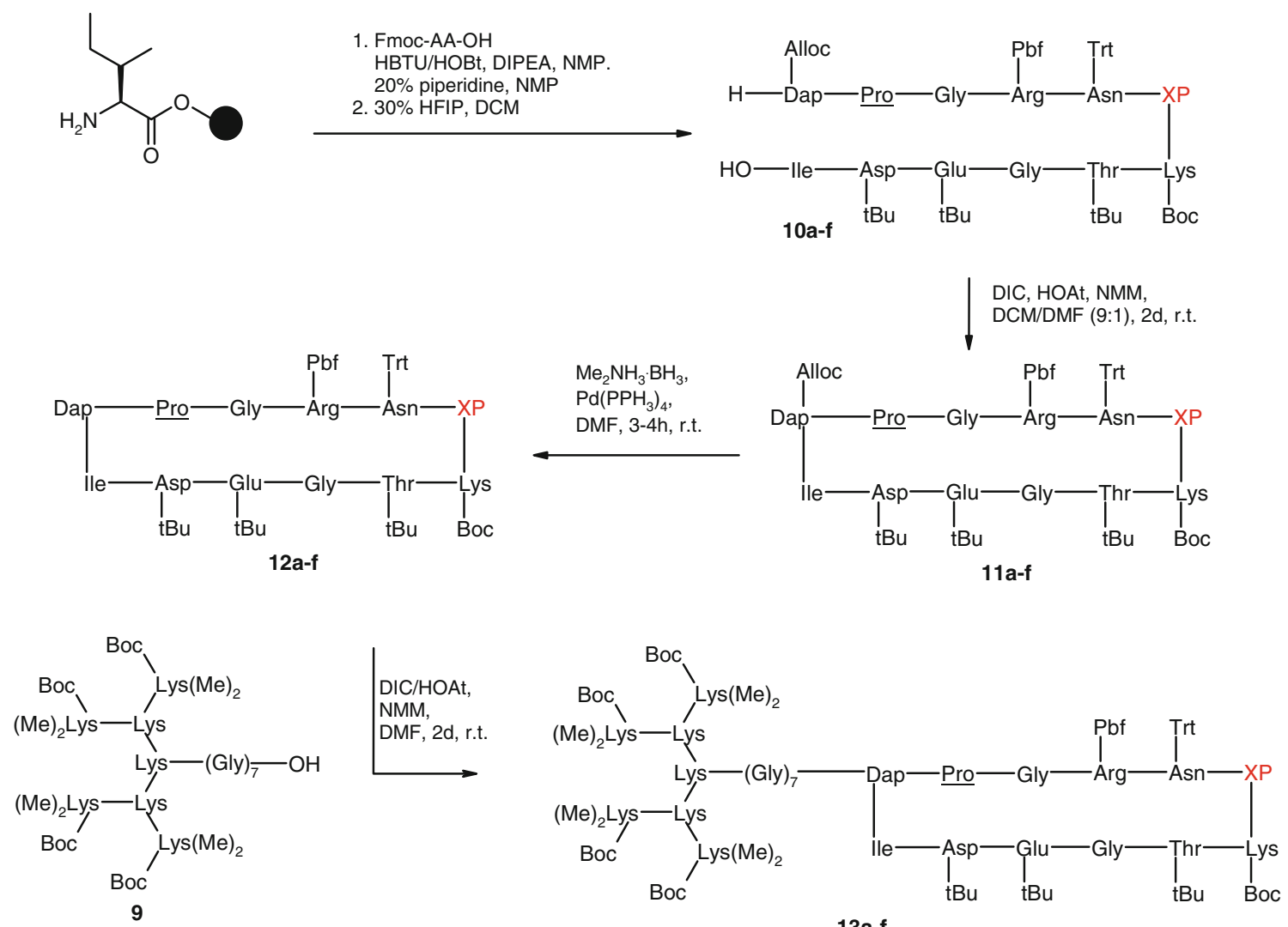

13a-f
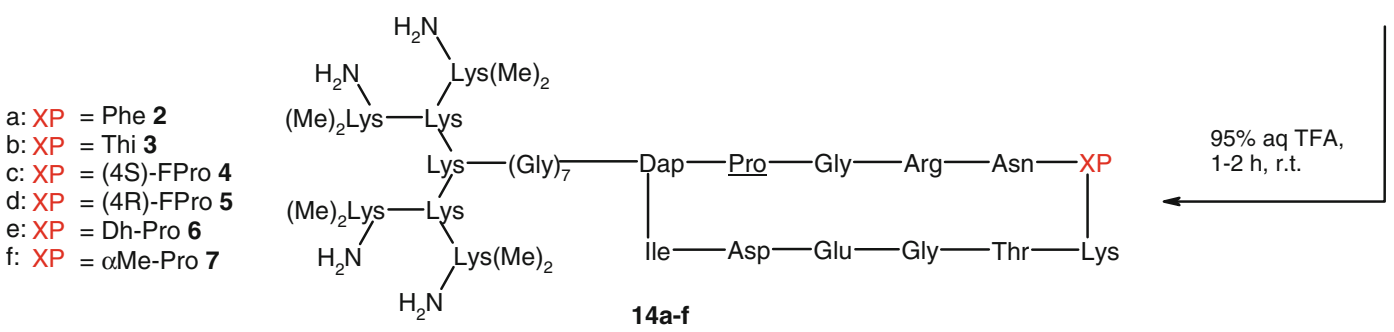

Scheme 1 Synthesis of IHF analogs with varying amino acid residue (XP) that mimics the intercalating proline
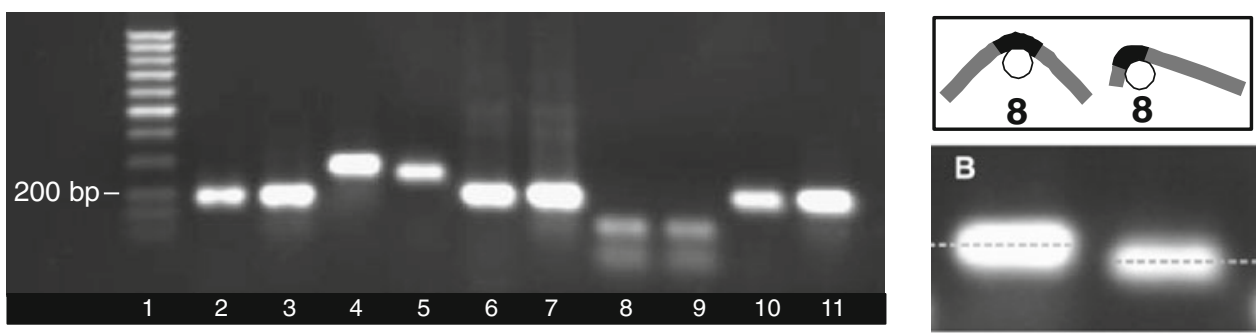

Fig. 4 Agarose gel electrophoresis (1\%). Left lane 1100 bp DNA marker, lanes 2 and 3200 bp DNA $\mathrm{H}^{\prime}$-middle and $\mathrm{H}^{\prime}$-edge, lanes 4 and 5 peptide 8 (Pro) +200 bp DNA $\mathrm{H}^{\prime}$-middle and $\mathrm{H}^{\prime}$-edge; lanes 6 and 7 peptide 8 (Pro) +200 bp DNA $\mathrm{H}^{\prime}$-middle and $\mathrm{H}^{\prime}$-edge + Tsp509 restriction enzyme, lanes 8 and 9200 bp DNA $\mathrm{H}^{\prime}$-middle and

configuration can be envisaged by (4R)-fluoroproline diastereomer stabilizing the triple helix of collagen, whereas the (4S)-diastereomer has an destabilizing effect (Barth
$\mathrm{H}^{\prime}$-edge + Tsp509 restriction enzyme, lanes 10 and 11200 bp DNA $\mathrm{H}^{\prime}$-edge and $\mathrm{H}^{\prime}$-middle. Right Enlargement of lanes 4 and 5 migration difference of mimic $\mathbf{8}$ binding in the middle or terminal position of 200 bp DNA

et al. 2004; Hodges and Raines 2003; Renner et al. 2001). The IHF-mimics were synthesized containing (4S)-FPro (14c) stabilizing the endo-conformation and (4R)-FPro 
Fig. 5 Agarose gel

electrophoresis (1\%). Left lane 1

100 bp DNA marker, lane 2

200 bp DNA, lanes 3 and 4 peptide 14a (Phe) $+200 \mathrm{bp}$ DNA $\mathrm{H}^{\prime}$-middle and $\mathrm{H}^{\prime}$-edge. Right lane 1100 bp DNA marker, lane 2200 bp DNA, lanes 3 and 4 peptide 14b (Thi) +200 bp DNA H'-middle and $\mathrm{H}^{\prime}$-edge
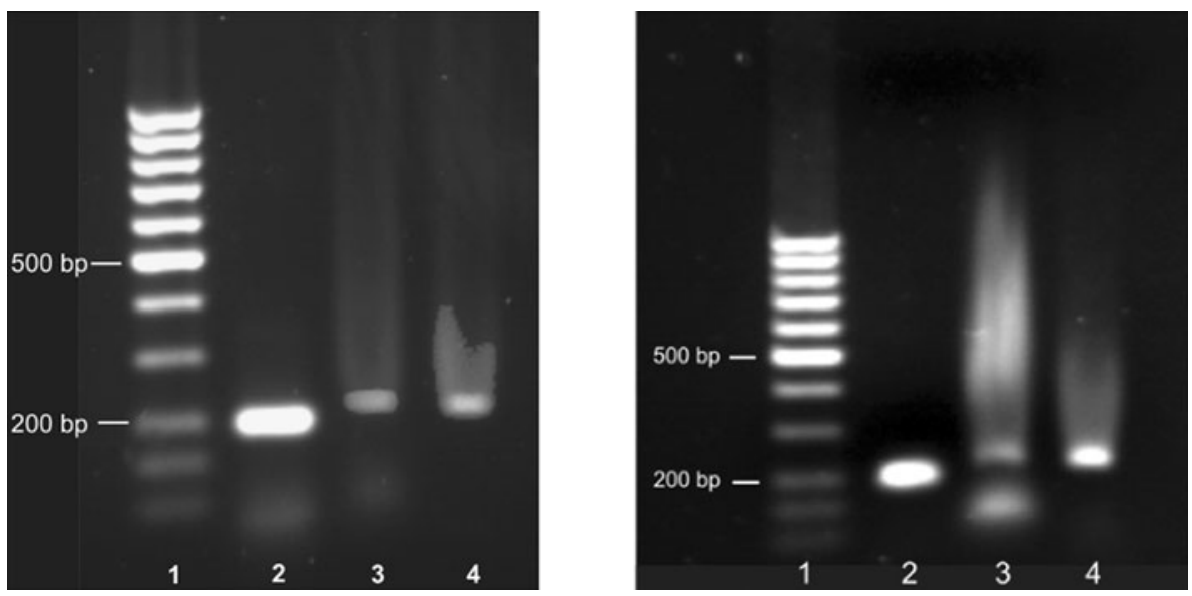

(14d) with preference for the exo-conformer. In a gel electrophoresis study with the $\mathrm{H}^{\prime}$-edge and $\mathrm{H}^{\prime}$-middle 200 bp DNA sequences (Fig. 7) for both peptides 14c and 14d retardation of the bands was recognized indicating the formation of recognition complexes between DNA and the IHF analogs. In comparison to the exo-Pro mimic, the endo-Pro intercalating peptide $\mathbf{1 4 c}$ provided a stronger band-shift but also lower specificity indicated by broader bands (lanes 8 and 9) whereas the bands of the exo-Pro peptide 14d in complex with dsDNA are sharp (lanes 10 and 11). The higher specificity of $\mathbf{1 4 d}$ is in accordance to the exo-Pro conformation of the $\alpha$-arm in the IHF/DNA cocrystal structure. In addition, there was no difference in binding of peptide $14 \mathbf{c}$ to the $\mathrm{H}^{\prime}$-edge or $\mathrm{H}^{\prime}$-middle position of the 200 bp DNA, whereas recognition of $\mathbf{1 4 d}$ provided slightly higher retardation for complexation at the $\mathrm{H}^{\prime}$ middle binding site due to a higher degree of curvature. From this experiment it can be concluded that recognition of the $\alpha$-arm of IHF is strongly relying on the exo-Pro65 conformation.

3,4-Dehydroproline provides a nearly planar five-membered ring (Benedetti et al. 1981; Fisher et al. 1978). In gel electrophoresis considering the interaction of the Dh-Pro modified IHF analog 14e with 200 bp DNA (Fig. 7, lanes 6 and 7) non specific binding was observed comparable to the endo-Pro peptide $\mathbf{1 4 c}$ interaction. The restriction to planar ring conformation seems to disturb proper fitting inhibiting specific recognition. Nevertheless, the interaction of peptide 14e with dsDNA is indicated by significantly shifted bands in the gel electrophoresis.

Finally, exchange of the intercalating proline in the $\alpha$-arm of IHF against $\alpha$-methylproline was performed synthesizing IHF analog 14f. $\alpha$-Methylproline has a $\beta$-turn inducing effect (Welsh et al. 1992; Hinds et al. 1991). Therefore, it was expected that an additional methyl group at the peptide backbone of the $\alpha$-arm of the IHF analogs strongly affects the cyclopeptide conformation. Indeed, in gel electrophoresis experiment of $200 \mathrm{bp}$ DNA with IHF analog $14 \mathbf{f}$ no indication of recognition was found (Fig. 7, lanes 12 and 13). The additional $\alpha$-methyl group at the intercalating proline significantly disturbs the $\beta$-sheet conformation of the minor groove binding loop thereby completely interrupting DNA binding.

$\mathrm{H}^{\prime}$-edge and $\mathrm{H}^{\prime}$-middle; lanes 4 and 5: peptide 8 (Pro) +200 bp DNA H'-edge and $\mathrm{H}^{\prime}$-middle (1:200); lanes 6 and 7: peptide 14e (Dh-Pro) +200 bp DNA $\mathrm{H}^{\prime}$-edge and $\mathrm{H}^{\prime}$-middle (1:200); lanes 8 and 9: peptide 14c ((4S)FPro $)+200 \mathrm{bp}$ DNA $\mathrm{H}^{\prime}$-edge and $\mathrm{H}^{\prime}$-middle (1:200); lanes 10 and 11: peptide 14d ((4R)-FPro) + 200 bp DNA $\mathrm{H}^{\prime}$-edge and $\mathrm{H}^{\prime}$-middle (1:200); lanes 12 and 13: peptide 14f $\alpha \mathrm{Me}-\mathrm{Pro})+200 \mathrm{bp}$ DNA $\mathrm{H}^{\prime}$-edge and $\mathrm{H}^{\prime}$-middle $(1: 200)$.

Fluorescence resonance energy transfer (FRET)

Integration host factor-induced bending of dsDNA was also analyzed by FRET using a 55 bp dsDNA (5' 6-FAM CCCAC GGCAT TATAA AAAAG CATTG CTTAT CAATT TGTTG CAACG AACAG GTCGG- $3^{\prime}+$ 5'-TAMRA GGGTG CCGTA ATATT TTTTC GTAAC

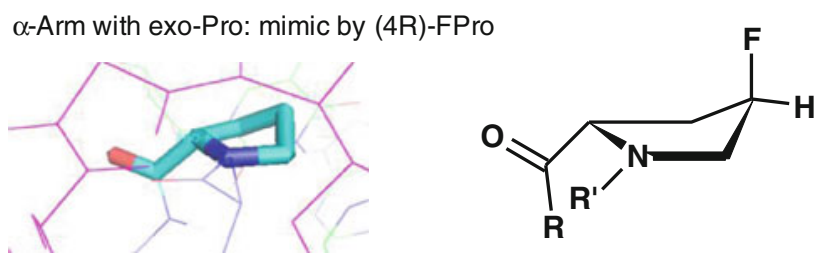

$\beta$-Arm with endo-Pro: mimic by (4S)-FPro
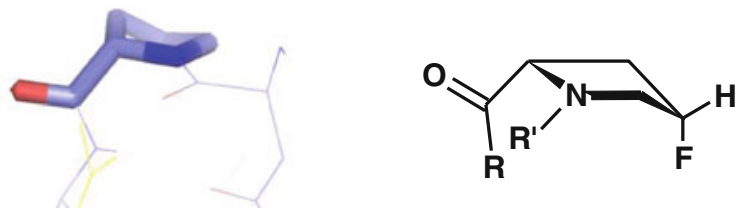

Fig. 6 Intercalating proline residues enlarged from the $\alpha$ and $\beta$-arm of the IHF DNA co-crystal structure (Rice et al. 1996) together with the respective fluoroproline derivatives as conformational mimics 


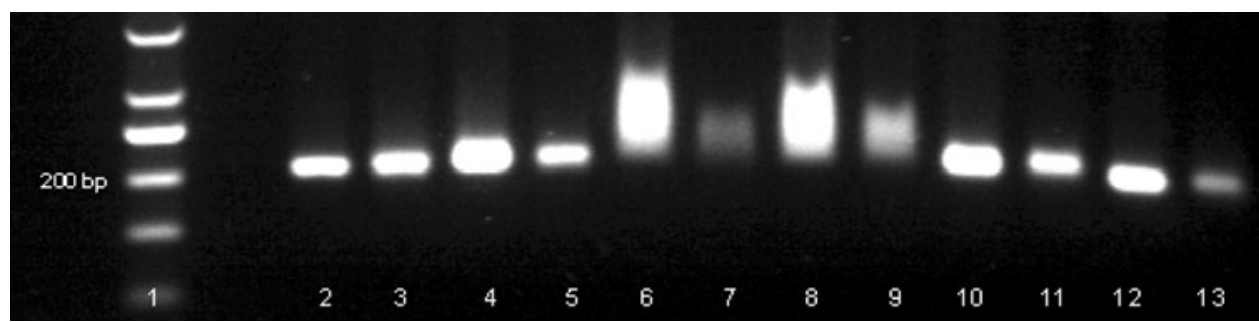

Fig. 7 Agarose gel electrophoresis (2\%): lane 150 bp DNA marker, lanes 2 and 3200 bp DNA H'-edge and H'-middle; lanes 4 and 5 peptide 8 (Pro) + 200 bp DNA H'-edge and H'-middle (1:200); lanes 6 and 7 peptide $14 \mathrm{e}$ (Dh-Pro) +200 bp DNA H'-edge and H'-middle (1:200); lanes 8 and 9 peptide 14c ((4S)-FPro) + 200 bp DNA

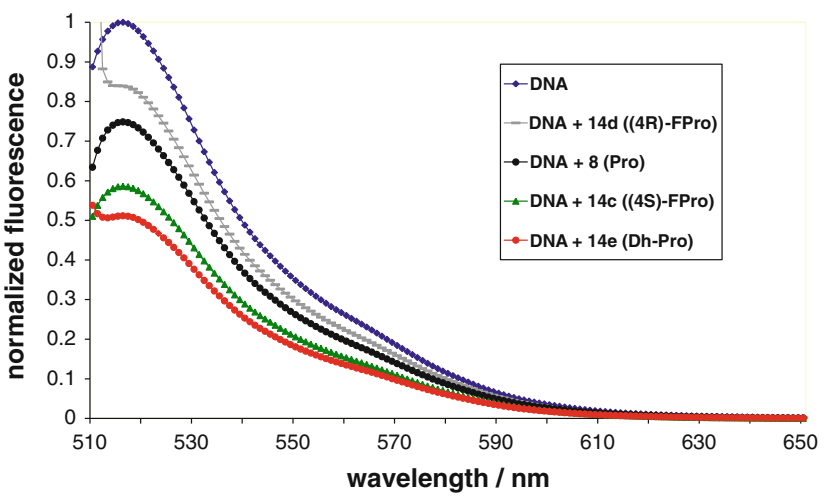

Fig. 8 Fluorescence emission spectra for 55 bp DNA and complexes with the IHF-mimics $\mathbf{8}$ and $\mathbf{1 4 c - e}$. Donor fluorescence spectra of the IHF-mimics $\mathbf{8}$ and $\mathbf{1 4 c}-\mathbf{e}$ were normalized to the fluorescence of the free 55 bp DNA

GAATA GTTAA ACAAC GTTGC TTGTC CAGCC- ${ }^{\prime}$ ) that contains the $\lambda$ phage $\mathrm{H}^{\prime}$-binding site and labeling of both $5^{\prime}$-terminal ends with fluorescein (FAM) and tetramethylrhodamine (TAMRA), respectively (Lorenz et al. 1999). Fluorescence quenching of about $50 \%$ was observed at $520 \mathrm{~nm}$ adding the DNA binding IHF domain which can be correlated to a fluorophore distance of $51 \AA$ in accordance to the crystal structure (Rice et al. 1996; Lorenz et al. 1999). The 55 bp fluorescence labeled DNA double strand used for the FRET with IHF/DNA experiments was also applied to investigate the bending potential of the IHF analogs 8 and 14c-e with modified Pro65 residue (Fig. 8). The IHF analog DNA complexes were analyzed in a 200:1 ratio using a Tris $\mathrm{HCl}$ buffer $(10 \mathrm{~mm}$ Tris- $\mathrm{HCl}$, $10 \mathrm{~mm}$ EDTA, $100 \mathrm{~mm} \mathrm{NaCl}, 1 \mathrm{~mm}$ dithiothreitol and $\mathrm{pH}$ 7.5 , incubated for $3 \mathrm{~h}$ at r.t. and excited at $496 \mathrm{~nm}$ ).

The proline IHF mimic $\mathbf{8}$ provided a fluorescence quenching effect of $25 \%$ in agreement with specific DNA binding not bending dsDNA to the same extent as IHF. The quenching effect induced by the (4R)-fluoroproline derivative 14d turned out to be even lower. This difference in
H'-edge and H'-middle (1:200); lanes 10 and 11 peptide $14 \mathrm{~d}((4 \mathrm{R})$ FPro) +200 bp DNA H'-edge and H'-middle (1:200); lanes 12 and 13 peptide $14 \mathrm{f} \alpha \mathrm{Me}$-Pro $)+200 \mathrm{bp}$ DNA H'-edge and $\mathrm{H}^{\prime}$-middle (1:200)

bending was already indicated by gel electrophoresis $(\mathbf{8}$ in Fig. 4 vs. 14d in Fig. 7). Nevertheless, the exo-conformation of Pro65 in the $\alpha$-arm of IHF resembled and well stabilized by (4R)-fluorine substitution seems to be decisive for recognition and binding specificity but does not lead to increased dsDNA bending. In contrast, the (4S)-fluoroproline and 3,4-dehydroproline derivatives $\mathbf{1 4 c}$ and 14e provided high fluorescence quenching of 42 and $50 \%$, respectively. Both derivatives were non-specificbinders according to gel electrophoresis. Charge interaction seems to gain more importance and non-specific binding implies that even more than one equivalent of peptide might be involved in dsDNA interaction.

\section{Conclusion}

The IHF protein domain bending dsDNA more than $160^{\circ}$ was imitated by a peptide composed of a lysine dendrimer linked to a cyclopeptide. The dendrimer provides the positive charges for non-specific binding and the cyclopeptide with a sequence related to the IHF $\alpha$-arm specifically binding in the minor groove. The Pro65 amino acid within the $\alpha$-arm is especially interesting since the ring is intercalated into the DNA base pair plane at the kinking position. A comparable study of IHF analogs was performed varying the proline derivatives. Larger aromatic residues like Phe and tetrahydroisoquinoline carboxylic acid were not tolerated as Pro substitutes. Introduction of the turn inducing $\alpha$-methylproline indicated the importance of the $\beta$-sheet like conformation of the $\alpha$-arm resembling cyclopeptide since binding was suppressed in the respective analog. The influence of the proline ring conformation was investigated by introduction of the endo-conformation stabilizing (4S)-fluoroproline and the exo-conformation preferring (4R)-fluoroproline. Specific binding was indicated only for the (4R)-FPro derivative imitating the exo-conformation that was found in the IHF/DNA co-crystal structure for 
Pro65 in the $\alpha$-arm. The (4S)-FPro turned out to be a DNA binder with lower specificity; comparable binding was obtained for 3,4-dehydroproline with a planar ring conformation. The preparation and DNA interaction of IHF mimics should be a useful tool for further understanding of protein/DNA recognition on the molecular level.

Acknowledgments Generous support of the Deutsche Forschungsgemeinschaft (IRTG 1422) is gratefully acknowledged. We thank Christiane Preiß for assistance in the in vitro recombination of the attP site ( $\lambda$ phage) and synthesis of the $200 \mathrm{bp}$ DNA.

Open Access This article is distributed under the terms of the Creative Commons Attribution Noncommercial License which permits any noncommercial use, distribution, and reproduction in any medium, provided the original author(s) and source are credited.

\section{References}

Albericio F (2002) Methoden der organischen Chemie (Houben Weyl) In Büchel KH (ed) Georg Thieme Verlag, Stuttgart, vol E 22a, pp 58-61

Barth D, Milbradt AG, Renner C, Moroder L (2004) A (4R)- or a (4S)-fluoroproline residue in position Xaa of the (Xaa-Yaa-Gly) collagen repeat severely affects triple-helix formation. Chembiochem 5:79-86

Benedetti E, Di Blasio B, Pavone V, Pedone C, Felix A, Goodman M (1981) Conformational studies of peptides: crystal and molecular structures of L-3,4-dehydroproline and its t-butoxycarbonyl and acetyl amide derivatives. Biopolymers 20:283-302

Benoiton L (1964) Amino acids and peptides; II. synthesis of $\varepsilon-N$-methyl-L-lysine and related compounds. Can J Chem 42:2043-2047

Bewley CA, Gronenborn AM, Clore GM (1998) Minor groovebinding architectural proteins: structure, function, and DNA recognition. Annu Rev Biophys Biomol Struct 27:105-131

Bollhagen R, Schmiedberger M, Barlos K, Grell E (1994) A new reagent for the cleavage of fully protected peptides synthesised on 2-chlorotrityl chloride resin. J Chem Soc Chem Commun 22:2260-2559

Drlica K, Rouviere-Yaniv J (1987) Histonelike proteins of bacteria. Microbiol Rev 51:301-319

Erdmann RS, Kümin M, Wennemers H (2009) (4R)- and (4S)Azidoprolines-conformation directing amino acids and sites for functionalization. Chimia 63:197-200

Fernandez-Forner D, Gasals G, Navarro E, Ryder H, Albericio F (2001) Solid-phase synthesis of 4-aminopiperidine analogues using the Alloc protecting group: an investigation of Alloc removal from secondary amines. Tetrahedron Lett 42:4471-4474

Filutowicz M, Appelt K (1988) The integration host factor of Escherichia coli binds to multiple sites at plasmid R6K $\gamma$ origin and is essential for replication. Nucl Acids Res 16:3829-3843

Fisher GH, Marlborough DI, Ryan JW, Felix AM (1978) L-3,4Dehydroproline analogs of bradykinin. Arch Biochem Biophys 189:81-85

Friedman DI (1988) Integration host factor: a protein for all reasons. Cell 55:545-554

Grove A, Saavedra TC (2002) The role of surface-exposed lysines in wrapping about the bacterial histone-like protein HU. Biochemistry $41: 7597-7603$
Hinds MG, Welsh JH, Brennand DM, Fisher M, Glennie MJ, Richards NGJ, Turner DL, Robinson JA (1991) Synthesis, conformational properties, and antibody recognition of peptides containing $\beta$-turn mimetics based on $\alpha$-alkylproline derivatives. J Med Chem 34:1777-1789

Hodges JA, Raines RT (2003) Stereoelectronic effects on collagen stability: the dichotomy of 4-fluoroproline diastereomers. J Am Chem Soc 125:9262-9263

Horng JC, Raines RT (2006) Stereoelectronic effects on polyproline conformation. Protein Sci 15:74-83

Hughes RM, Benshoff ML, Waters ML (2007) Effects of chain length and $N$-methylation on a cation- $\pi$ interaction in a $\beta$-hairpin peptide. Chem Eur J 13:5753-5764

Kim W, Hardcastle KI, Conticello VP (2006) Fluroproline flip-flop: regiochemical reversal of a stereoelectronic effect on peptide and protein structures. Angew Chem 118:8321-8325

Lesarri A, Cocinero EJ, López JC, Alonso JL (2005) Shape of $(4 S)$ - and (4R)-hydroxyproline in gas phase. J Am Chem Soc 127:2572-2579

Liebler EK, Diederichsen U (2004) From IHF protein to design and synthesis of a sequence-specific DNA bending peptide. Org Lett 6:2893-2896

Lorenz M, Hillisch A, Goodman SD, Diekman S (1999) Global structure similarities of intact and nicked DNA complexed with IHF measured in solution by fluorescence resonance energy transfer. Nucl Acids Res 27:4619-4625

Moitoso de Vargas L, Kim S, Landy A (1989) DNA looping generated by two bending protein IHF and two domains of lambda integrase. Science 244:1457-1461

Naduthambi D, Zondlo NJ (2006) Stereoelectronic tuning of the structure and stability of the Trp cage miniprotein. J Am Chem Soc 128:12430-12431

Pettijohn DE (1988) Histone-like proteins and bacterial chromosome structure. J Biol Chem 263:12793-12796

Renner C, Alefelder S, Bae JH, Budisa N, Huber R, Moroder L (2001) Fluoroprolines as tools for protein design and engineering. Angew Chem Int Ed 40:923-925

Rice PA (1997) Making DNA do a U-turn: IHF and related proteins. Curr Opin Struct Biol 7:86-93

Rice PA, Yang S, Mizuuchi K, Nash HA (1996) Crystal structure of an IHF-DNA complex: a protein-induced DNA U-turn. Cell 87:1295-1306

Ruan F, Chen Y, Itoh K, Sasaki T, Hopkins PB (1991) Synthesis of peptides containing unnatural, metal-ligating residues: aminodiacetic acid as a peptide side chain. J Org Chem 56:4347-4354

Shoulders MD, Hodges JA, Raines RT (2006) Reciprocity of steric and stereoelectronic effects in the collagen triple helix. J Am Chem Soc 128:8112-8113

Sonntag LS, Schweizer S, Ochsenfeld C, Wennemers H (2006) The "Azido Gauche Effect"-implications for the conformation of Azidoprolines. J Am Chem Soc 128:14697-14703

Swinger KK, Rice PA (2004) IHF and HU: flexible architects of bent DNA. Curr Opin Struct Biol 14:28-35

Ussery D, Larsen TS, Wilkes KT, Friis C, Worning P, Krogh A, Brunak S (2001) Genome organisation and chromatin structure in Escherichia coli. Biochimie 83:201-212

Welsh JH, Zerbe O, von Philipsborn W, Robinson JA (1992) $\beta$-Turns induced in bradykinin by $(S)$ - $\alpha$-methylproline. FEBS Lett 297:216-220

Wu HM, Crothers DM (1984) The locus of sequence-directed and protein-induced DNA bending. Nature 308:509-513 